4 Zahra Jamsazzadeh Kermani ${ }^{a}$, Avi Shpigelman ${ }^{b}$, Tom M.M. Bernaerts ${ }^{a}$, Ann M. Van Loey ${ }^{a}$,

\section{The effect of exogenous enzymes and mechanical treatment on mango purée: Microscopic, mesoscopic, and macroscopic evaluation}

(1)
Marc E. Hendrickx ${ }^{a}$ *

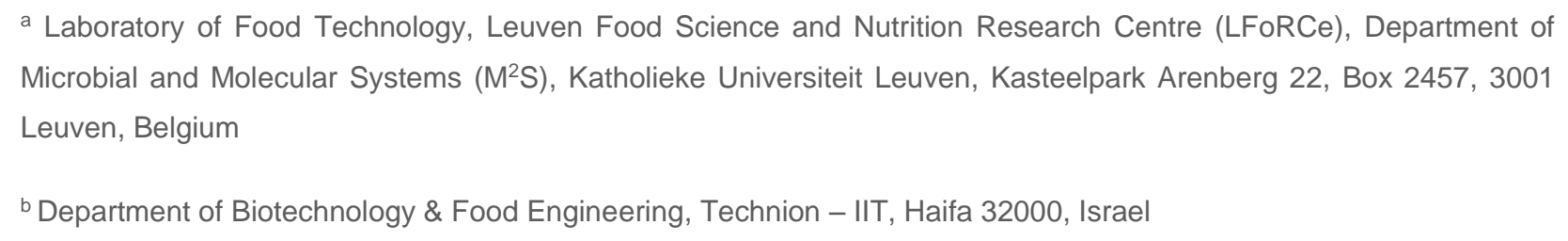

(10)

(1)

Authors are affiliated to:

Laboratory of Food Technology

Leuven Food Science and Nutrition Research Center (LFoRCe)

Department of Microbial and Molecular Systems (M²S)

KU Leuven

Kasteelpark Arenberg 22 box 2457

3001 Heverlee

Belgium

20

1 * Corresponding author

2 Fax: +32 16321960

Telephone: +3216321572

4 E-mail: marc.hendrickx@biw.kuleuven.be

25

26

27 
29 This paper addresses to what extent mango purée macroscopic properties (consistency) is related 30 to its particle physical properties such as mesoscopic (particle size) and microscopic (morphology) 31 properties. To manipulate mango purée particle sizes, high pressure homogenization (HPH) was 32 used. Commercial fungal and bacterial (cell wall) polysaccharide degrading enzymes without/with $33 \mathrm{HPH}$ (different sequences) were used to understand the contribution of specific (cell wall) 34 polysaccharides and the relevant parameters to consistency changes. The results reflect that, 35 unlike endo-cellulase, pectin methylesterase (PME) together with endo-polygalacturonase (PG), 36 and a-amylase significantly contributed to consistency decrease. HPH only, although largely 37 changing the particle size, did not change the purée consistency, but the combination of HPH with 38 an enzymatic treatment decreased it substantially. Enzymes, while having minimal effect on 39 particle sizes, induced a type-dependent modification of particles' morphology, showing the 40 accessibility of particle polymers (in addition to the expected serum polymers) to enzymes.

51 Keywords: Exogenous enzymes, High pressure homogenization, Consistency, Mango purée, 52 Particle properties. 


\section{Introduction}

54 Mango purée, generally preserved by canning, is one of the most popular mango products and is

55 used for the production of jams, squash and juice (Ahmed, Ramaswamy, \& Hiremath, 2005;

56 Manohar, Ramakrishna, \& Udayasankar, 1991). To produce mango purée, a mechanical

57 disintegration of the tissue is required, whereby a concentrated suspension is formed consisting

58 of mango-tissue-based particles in a continuous serum phase mainly containing soluble

59 polysaccharide such as pectin, sugars and organic acids (Moelants et al., 2013). Pectin is a plant

60 cell wall hetero-polysaccharide rich in galacturonic acid (GalA), which may be methyl-esterified at

61 C-6, and can be O-acetylated at the O-2 and/or O-3. Next to the predominant pectic component

62 GalA, pectin can be composed of 17 different monosaccharides (Vincken et al., 2003; Voragen,

63 Coenen, Verhoef, \& Schols, 2009). Due to the process of disintegration, pectin can be either found

64 in the liquid serum phase (soluble pectin) and/or as part of the cell wall material in the particle

65 phase. The amount of pectin in either of the phases depends on the extent pectin is bound to the

cell wall, and the processing history (e.g. blanching) prior to disintegration. The amount of pectin and pectin molecular characteristics of both phases influence the rheological properties of the purée by affecting on the one hand particle interactions and on the other hand serum viscosity (Moelants et al., 2012). For example pectin-rich fruits such as mango, having $0.4-0.5 \%$ pectin content (fresh weight), yield high viscous juices that together with the pulp form a jellified mass (Kashyap, Vohra, Chopra, \& Tewari, 2001; Varanyanond, Naohara, Wongkrajang, \& Manabe, 1999; Yashoda, Prabha, \& Tharanathan, 2006). Kansci et al., (2008) ascribed such high viscosity of mango purée to its high pectin content. Manohar et al., (1990) stated that the pectin content of mango purée, produced by a fruit pulper, has a critical effect on viscosity to an extent that a $5.7 \%$ reduction in pectin content reduced viscosity up to $50 \%$. As mango fruit contains $85 \%$ water, concentration of the mango purée is pursued as this process not only minimizes the cost of packaging for export, but also reduces the expense of further processing at destination. However, 
79 evaporators and for now any attempt for concentrating mango purée as such would not be without

80 suffering from extensive detrimental effects on its quality (Singh, Dhuique-Mayer, \& Lozano,

81 2000). Next to the pectin content and molecular properties of the pectic polymers of both phases,

82 mesoscopic (particle size) as well as microscopic characteristics (particle morphology) of the

83 particle phase might influence the macroscopic properties (consistency) of the purée (Moelants et

84 al., 2014). In addition, apart from pectin, other polymers such as starch could contribute to the

85 high viscosity of starch containing fruits including mango ( $0.1 \%$ starch based on fresh weight)

86 (Yashoda et al., 2006). At gelatinization temperature $\left(55-80^{\circ} \mathrm{C}\right.$, which is far below the common

87 blanching temperature, i.e., $95^{\circ} \mathrm{C}$ ), starch granules absorb water and swell (Swinkels, 1985). This

88 sudden water uptake leads to a strong increase in the system viscosity, but also to enzymatic

89 vulnerability of the starch (Uhlig \& Linsmaier-Bednar, 1998).

90 To date to concentrate a high viscous purée, two approaches have been suggested in literature.

91 One is concentration of mango purée to higher ${ }^{\circ}$ Brix using the principle of split-stream processing,

92 i.e., separation of serum from pulp followed by concentration of the serum only, that was

93 successful to some extent (Singh et al., 2000). The second suggested approach is enzymatic

94 liquefaction of mango purée followed by concentration (Bhat, 2000; Singh et al., 2000; Sreenath,

95 Nanjundaswamy, \& Sreekantiah, 1987; Sreenath, Sudarshana Krishna, \& Santhanam, 1995).

96 Enzymes are used as a processing aid to simplify intermediate processes such as decreasing the

97 viscosity of fruit pulp and increasing filterability of juices in modern food industry (Grassin \&

98 Fauquembergue, 1996; Singh et al., 2000). As enzymes are active at low concentration with a

99 reasonable rate under mild processing conditions (temperature, pH) (Fellows, 2000), studies

100 related to the application of exogenous enzymes in food industry have greatly multiplied in recent

101 years (Bhat, 2000; Schmelter, Wientjes, Vreeker, \& Klaffke, 2002; Singh et al., 2000; Sreenath et

102 al., 1995). Currently, a combination of pectinases (pectin lyase, pectin methylesterase, endo- and

103 exo-polygalacturonases, pectin acetylesterase, rhamnogalacturonase, endo- and exo- 
arabinases), cellulases (endo glucanases, exoglucanases and cellubiases) and hemicellulases (endo- and exo-xylanases, galactanases, xyloglucanases and mannanases), collectively called macerating enzymes, are used for fruit and vegetables juice extraction and clarification, but also to decrease viscosity of fruit purée and facilitate purée concentration (Bhat, 2000). Apart from the abovementioned cell wall degrading enzymes, a-amylase (non-cell wall degrading enzyme) is used to eliminate the starch haze formation for starch containing fruits such as apple, harvested during the early stage, and to reduce the viscosity of such juices (Bhat, 2000; Fellows, 2000). Using exogenous enzymes, one must take two issues into consideration. Firstly, depending on

112 the type of enzymes used, enzyme-treated pectins would potentially represent different 113 applications (Schmelter et al., 2002). Secondly, as each type of fruit has specific quantities and 114 ratios of pectin, hemicelluloses and cellulose in the cell walls, it is necessary to choose the right 115 enzyme preparation in relation to the fruit composition and the final product targeted (Grassin \& 116 Fauquembergue, 1996). Modern biotechnology has made it possible to produce purified 117 pectinolytic enzymes at commercial scale (Heldt-Hansen et al., 1996). Hence new doors open towards an efficient application for a tailor-made combination of such enzymes for maximum optimal performance over the present commercial macerating enzymes for certain matrices 120 (Heldt-Hansen et al., 1996).

121 To obtain low viscosity mango purée from ripe mango, two aspects need to be considered. On the 122 one hand the pectin content of the serum or particle phase should be influenced. This could be 123 achieved by tailoring pectin solubility influencing pectin molecular weight (depolymerizing 124 enzymes) and degree of methoxylation (demethoxylating enzymes). On the other hand, it is known 125 that in ripe mango next to pectin, starch ( $\sim 0.1 \%$ fresh weight) (Yashoda et al., 2006)and rather 126 significant amounts of cellulose in cell walls are present (Mitcham \& McDonald, 1992; Ollé, 127 Lozano, \& Brillouet, 1996). So the effect of enzymatic degradation of other polymers in mango 128 purée should also be scrutinized. 
129 High pressure homogenization $(\mathrm{HPH})$ that is known to result in particle disintegration, on the one 130 hand could assist the enzymatic treatment by increasing the enzyme substrate contact and on the 131 other hand might result in mechanical solubilization of pectin, changing pectin content in serum 132 and particle phase (Moelants et al., 2012).

133 The use of multicomponent commercial enzymes such as Pectinex ${ }^{\circledR}$, Celluclast ${ }^{\circledR}$ and/or a 134 mixture of the two, to manipulate mango purée rheological properties has already been reported 135 in several studies with the aim of optimizing the incubation conditions or investigating 136 physicochemical changes thereof (Bhattacharya \& Rastogi, 1998; Singh et al., 2000; Sreenath et 137 al., 1987; Sreenath et al., 1995). However as fruit purées are complex systems, it would be difficult 138 to relate the results observed from multicomponent enzymes to single polymer characteristics. To 139 the best of our knowledge, no studies were performed on the possibility of utilizing HPH separately 140 and in combination with enzymes for decreasing the mango purée consistency. In previous work 141 (Jamsazzadeh Kermani, Shpigelman, Bernaerts, Van Loey, \& Hendrickx, 2015), we showed that 142 for both particle and serum phase of mango purée the chemical composition and characteristics 143 of pectin polymers such as degree of methoxylation, average molecular weight, conformational 144 changes of specific polymers, and possible associations and entanglements between the 145 polymers are extensively influenced upon (combined) enzymatic and mechanical treatment. 146 However to what extent such pectin modifications upon treatments influence the macroscopic 147 property (consistency), in relation to mesoscopic (particle size) as well as microscopic (particle 148 morphology) properties of mango purée are still unknown. This study was carried out to investigate 149 how enzymatic treatments with and without HPH affect the consistency of mango purée in order 150 to better understand the parameters resulting in high consistency and how they can be 151 manipulated. Purified fungal and bacterial commercial enzymes (enzymatic treatment) presented 152 the possibility to evaluate the contribution of each individual enzyme to consistency decrease. To 
153 optimize the process and to increase the understanding of the effect of relevant parameters, 154 different sequences of enzymatic and mechanical treatments were applied.

\section{Materials and methods}

\subsection{Plant material}

157 Ripe mangos (Mangifera indica L.) of Keitt cultivar $(\mathrm{pH}=4.2$; Brix $=16.8 \% \pm 0.04)$ were purchased

158 in a local shop in Belgium. Mangos were thoroughly washed with demineralized water, dried and 159 peeled with a stainless steel knife.

$160 \quad$ 2.2. Sample preparation

161 The schematic overview of the sample preparation and experimental set-up is presented in Fig.

162 1. Mango flesh was sliced into layers of $1 \mathrm{~cm}$ thickness and vacuum-packed in polyethylene bags 163 in a single layer. To inactivate the endogenous enzymes in order to prevent enzymatic degradation 164 during storage, thawing, and further manipulation, mango flesh was blanched for 8 min at $95^{\circ} \mathrm{C}$ 165 in a temperature-controlled water bath. Immediately after the treatment, the bags were transferred 166 to an ice bath, frozen with liquid nitrogen and stored at $-40^{\circ} \mathrm{C}$.

167 Mango purée from blanched slices was obtained by blending (Waring blender 8010 EB, 168 Torrington, CT, USA) $600 \mathrm{~g}$ mango slices for $30 \mathrm{~s}$ at high speed. To prevent biased conclusions 169 originating from variability of individual specimens, for the whole experimental set-up $44 \mathrm{~kg}$ of 170 blanched purée was prepared likewise and mixed. Aiming different objectives, mango purée was 171 processed using five different treatments, i.e., mechanical treatment (HPH), enzymatic treatment,

$172 \mathrm{HPH}$ followed by enzymatic treatment, enzymatic treatment immediately followed by $\mathrm{HPH}$, 173 incubation of purée with enzymes followed by HPH. All treatments were performed in duplicate. 174 All samples were re-blanched $\left(8 \mathrm{~min}\right.$ at $\left.95^{\circ} \mathrm{C}\right)$ after the above mentioned treatments to inactivate 175 the exogenous enzymes added. Samples without added enzymes were also blanched aiming for 
176 a fair comparison between enzymatic and non-enzymatic treatments. After blanching, purées

177 were cooled in an ice bath and equilibrated at $25^{\circ} \mathrm{C}$ for $15 \mathrm{~min}$. The treated purées were 178 subsequently used for consistency and particle size distribution measurements and microscopic 179 imaging.

\subsection{Mechanical treatment}

181

Mango purée was first defrosted in a water bath at $25{ }^{\circ} \mathrm{C}$ for approximately $15 \mathrm{~min}$. Then demineralized water was added (50\% of the total amount of aqueous phase added at the end, 10 $\mathrm{ml}$ for $200 \mathrm{~g}$ of purée), and the $\mathrm{pH}$ was adjusted to 5.0. The obtained purée was homogenized at 20, 60 or $100 \mathrm{MPa}$ via a single pass, using a Panda 2k high-pressure homogenizer (Niro Soavi, Parma, Italy), of which the in- and outlet were thermostated at $4{ }^{\circ} \mathrm{C}$ using a cryostat (Haake, Karlsruhe, Germany). Homogenized purées were vacuum packed in plastic bags and incubated for $1 \mathrm{~h}$ in a shaking water bath at $40^{\circ} \mathrm{C}$. Immediately after incubation, the bags were put in a water bath at $95{ }^{\circ} \mathrm{C}$ for $8 \mathrm{~min}$ and cooled in an ice bath for $5 \mathrm{~min}$. Taking into account the volumes of water and alkaline solution $(1 \mathrm{M} \mathrm{NaOH})$ already added in the previous steps to adjust $\mathrm{pH}$, demineralized water was added to obtain purée with a ratio of 1:10 added aqueous phase:purée (at the end, having $20 \mathrm{ml}$ of aqueous phase for $200 \mathrm{~g}$ of purée).

\subsection{Enzymatic treatment}

Commercial pectinmethylesterase (PME) (Novoshape, Novozymes), and ultrapure endopolygalacturonase (PG) from Aspergillus aculeatus (Megazyme), bacterial a-amylase from Bacillus sp. (Sigma-Aldrich) and fungal endo-cellulase (endo- $\beta$-glucanase) referred as cellulase in this paper from Aspergillus niger (Megazyme) were used. Preliminary experiments showed complete solidification of mango purée using PME alone (results not shown), suggesting that possible impurities can be considered negligible. CBM3a, an antibody to recognize crystalline cellulose, did not label the control and cellulase treated samples (images not shown). It might be 
speculated that if present, the crystalline cellulose part was sterically inaccessible for the antibody.

This was one of the reasons why pure endo glucanase was used for the enzymatic treatment as this enzyme specifically degrades amorphous cellulose (Cao \& Tan, 2002).

203 After defrosting the purée, $\mathrm{pH}$ was adjusted to the optimal pH as claimed by the provider (5.5, 6.0.

4.5, 5.5) for each of the enzymatic treatments: "PG and PME", "a-amylase", "cellulase", and

"combination of PG and PME, $\alpha$-amylase and cellulase" referred to as "all enzymes" treated purée,

respectively. One unit ${ }^{1}(U)$ of each individual enzyme was added to $1 \mathrm{~g}$ of total purée (including

207 the added aqueous phase) (Table 1). All purées were vacuum packed in plastic bags and

was used to inactivate the enzymes after incubation. The $\mathrm{pH}$ of the purées was re-adjusted to 5.0.

Finally, demineralized water was added to obtain the ratio of 1:10 aqueous phase:purée considering the volumes of added water, enzymes, alkaline $(1 \mathrm{M} \mathrm{NaOH})$ and acid $(0.1 \mathrm{M} \mathrm{HCl})$ solutions (used for pH adjustments) (Jamsazzadeh Kermani et al., 2015).

\subsection{Combination of mechanical and enzymatic treatment}

\subsubsection{High pressure homogenization followed by enzymatic treatment}

215 Mango purée was initially homogenized at $20 \mathrm{MPa}$ using a Panda 2k high-pressure homogenizer

216 (Niro Soavi, Parma, Italy), followed by $\mathrm{pH}$ adjustment (to the optimal $\mathrm{pH}$ of the applied enzymes)

217 and enzyme addition. Compared to the enzymatic treatment only, the combined effect of HPH and

218 "PG and PME" together with "a-amylase" on the properties of the purée obtained was also

219 evaluated. For such treatment, the $\mathrm{pH}$ of the mango purée was adjusted to 5.5 prior to addition of

\footnotetext{
${ }^{1}$ One unit of PG is defined as the amount of enzyme releasing $1 \mu \mathrm{mol}$ of galacturonic acid per min at pH 5.5 at $40^{\circ} \mathrm{C}$ (Combo, Aguedo, Goffin, Wathelet, \& Paquot, 2012). One unit of PME is defined as the amount of enzyme catalyzing the hydrolysis of $1 \mu \mathrm{mol}$ of ester bonds per min at $\mathrm{pH} 7.0$ and $22^{\circ} \mathrm{C}$. One unit of $\alpha$-amylase liberates $1.0 \mathrm{mg}$ of maltose from starch in $3 \mathrm{~min}$ at $\mathrm{pH} 6.9$ at $20^{\circ} \mathrm{C}$ (Enzymatic assay, Sigma). One unit of cellulase is defined as the amount of enzyme required to release $1 \mu \mathrm{mol}$ of 2-chloro-4-nitrophenol from CellG3 in 1 min under assay conditions at $40^{\circ} \mathrm{C}$ (Enzymatic, Megazyme).
} 
220 the enzymes. The same proportion of enzymes, incubation and blanching conditions were used

221 as in the enzymatic treatment described in Section 2.4. The $\mathrm{pH}$ was re-adjusted to 5.0 and water

222 was added to achieve the ratio of 1:10 aqueous phase:purée, analogous to the enzymatic

223 treatment. For the control purée the addition of exogenous enzymes was excluded (Jamsazzadeh

224 Kermani et al., 2015).

\subsubsection{Enzymatic treatment immediately followed by $\mathrm{HPH}$}

226 For this treatment, after the addition of respective enzymes (Section 2.4), purées were 227 immediately homogenized at $20 \mathrm{MPa}$ and the homogenized purées were vacuum packed in plastic 228 bags and incubated for $1 \mathrm{~h}$ at $40{ }^{\circ} \mathrm{C}$ in a shaking water bath. After incubation, the $\mathrm{pH}$ was re229 adjusted to 5.0 and the final ratio of aqueous phase:purée was adjusted to 1:10. For the control 230 purée, the addition of exogenous enzymes was excluded.

\subsubsection{Incubation of purée with enzymes followed by HPH}

232 Similar to Section 2.5.2, exogenous enzymes were added to purées but the HPH treatment was 233 performed after incubating the purées for $1 \mathrm{~h}$ at $40^{\circ} \mathrm{C}$. Before the $\mathrm{HPH}$ treatment, the $\mathrm{pH}$ of the 234 purées was adjusted to 5.0 and purées subsequently homogenized at $20 \mathrm{MPa}$. The ratio of 235 aqueous phase to purée was adjusted after $\mathrm{HPH}$. For the control purée, the addition of exogenous 236 enzymes was excluded.

\subsection{Rheological characteristic of mango purée}

\section{Bostwick consistency measurement}

239 In practice, Bostwick consistency is frequently used to describe the rheological behavior of a non240 Newtonian food product such as fruit purée (Perona, 2005). In this emperical test, the sample 241 flows under its own weight at certain temperatrue for $30 \mathrm{~s}$. The distance that the sample flows over 242 this time is measured and reported as Bostwick consistency index (Christiaens et al., 2012). 243 Bostwick consistency summarize variability of viscosity into a unique mean value and quantifies 
244 such value as the mean resistance that the fluid experiences against deformation under gravity-

245 driven flow. Since this value could be an equivalent for the mean viscosity, this technique is of

246 large inteterst thanks to its speed and simplicity (Perona, 2005). A high Bostwick consistency index

247 corresponds to a purée having low consistency which has a low resistance to flow and vice versa.

248 Approximately $100 \mathrm{~g}$ mango homogenate $\left(24^{\circ} \mathrm{C} \pm 1\right)$ was poured into the reservoir and after an

249 equlibration time of $1 \mathrm{~min}$ in the reservoir, the consistency was assessed by opening the gate of

250 the reservoir of Bostwick consistometer (Tibäck et al., 2009). All measurements were conducted

251 in duplo.

$252 \quad$ 2.7. Structural characteristic of the particles

253 Particle size distribution

254 The particle size distribution (PSD) of mango purée was measured using laser diffraction 255 (Beckman Coulter Inc., LS 13 320, Miami, Florida). Hereto, samples were poured into a stirred 256 tank, filled with demineralized water and pumped into the measuring cell wherein the laser light 257 (wavelength main illumination source: $750 \mathrm{~nm}$; wavelengths tungsten-halogen light for 258 Polarization Intensity Differential Scattering (PIDS): $450 \mathrm{~nm}, 600 \mathrm{~nm}, 900 \mathrm{~nm}$ ) was scattered by 259 the particles (particles between $0.04 \mu \mathrm{m}$ and $2000 \mu \mathrm{m}$ can be detected) (Verrijssen et al., 2014).

260 The volumetric PSDs were calculated from the intensity profile of the scattered light with

261 Fraunhofer optical model using the instrument's software. Some deviations from the correct 262 particle size might occur for the samples where most of the particles are $<10 \mu \mathrm{m}$ due to possible 263 deviation from the Mie theory (Jamsazzadeh Kermani, Shpigelman, Pham, Van Loey, \& 264 Hendrickx, 2015).

\subsection{Bright field microscopy}

266 Microscopic pictures were taken to visualize the microstructure of the particles after enzymatic 267 and mechanical treatment. Light microscope (Olympus BX-41) equipped with an Olympus XC-50 
268 digital camera (Olympus, Opticel Co. Ltd., Tokyo, Japan) was used with an objective of 10x or $26940 \times$ for magnification using either bright field or differential interference contrast mode (DIC). 270 lodine solution (containing $0.2 \%$ iodine and $2 \%$ potassium iodide) and toluidine blue solution were 271 used to stain starch polymers and the cell walls respectively. At least ten images were obtained 272 per sample.

\section{$273 \quad$ 2.9. Statistical analysis}

274 Differences in mean values for the Bostwick consistency indices were estimated using one-way 275 ANOVA. Pairwise comparison of the means were performed using the Tukey's Test $(P<0.05)$ 276 (Origin Pro, version 8.0724, MA01060 U.S.A.).

\section{Results and discussion}

278 The different treatments used in this study aimed at different goals. The objective of the HPH 279 treatment only, was mainly to affect the particle sizes by disaggregation and disruption of cell 280 clusters and individual cells in the purée and investigate to what extent such changes influence 281 Bostwick consistency of the purée. Enzymatic treatments were performed with the aim of mainly 282 influencing enzyme-accessible polymers from serum and particle phase. In our previous study 283 (Jamsazzadeh Kermani et al., 2015), it was shown that when (non) homogenised purée was enzymatically treated, the chemical properties of pectin polymers of the serum as well as the paricles were largely influenced. Therefore to understand whether there is a mutual synergistic effect of $\mathrm{HPH}$ and enzymatic treatments on the flow properties of mango purée, such treatments were applied in differenct orders. Hereto, when HPH followed by enzymatic treatment was performed, the goal was to generate more accessible substrates for the enzymes by cells disruption while the aim of enzymatic treatment immediately followed by HPH was to investigate 290 whether possible stimulation of enzymes due to HPH can modify polysaccharide structure and 291 affect consistency. Finally, when purées were enzymatically treated for $1 \mathrm{~h}$ and subsequently 
292 homogenised, the goal was to investigate the sensitivity of the enzyamtically modified systems to 293 mechanical treatment thereof.

\section{3.1. State of starch prior to enzymatic treatment}

295 Starch gelatinization is a prerequisite for enzymatic hydrolysis of starch by a-amylases. To confirm 296 that the applied blanching condition $\left(95^{\circ} \mathrm{C}\right.$ for $8 \mathrm{~min}$ ) prior to enzymatic treatment gelatinized 297 mango starch, the effect of the blanching on the starch granules was visualized using polarized 298 light and is shown in Fig. 2. It is clear from Fig. 2 that when blanched mango purée (Fig. 2B) and 299 mango flesh tissue (Fig. 2A) were compared under polarized light, no Maltese crosses (loss of 300 birefringence) for the blanched purée were observed even for the smallest starch granules which 301 are believed to be gelatinized at higher temperature (Swinkels, 1985). This shows that the applied 302 blanching temperature was beyond the temperature range of mango starch gelatinization and all 303 the starch granules were in the gelatinized state prior to enzymatic treatment. This is in agreement 304 with previous published data on mango starch gelatinization for which a gelatinization temperature 305 of $73.8^{\circ} \mathrm{C}$ was reported (Millan-Testa, Mendez-Montealvo, Ottenhof, Farhat, \& Bello-Pérez, 306 2005). On the other hand, when mango flesh tissue and blanched mango purée were stained by 307 iodine solution and visualized using differential interference contrast mode (DIC) (Fig. 2A and 2B), 308 giant starch granules in a purplish background was observed. As appreciable swelling, and 309 noticeable disruption of the starch granules (observed as swollen granule fragments (Fig. 2B)) 310 occurred, it seems that apart from the gelatinization temperature and loss of birefringence, the 311 pasting temperature was reached. Reaching of mango starch to pasting temperature upon 312 blanching prior to enzymatic/combined enzymatic and mechanical treatment might explain a 313 partial potential role of starch to the high consistency of the blanched mango purée (Swinkels, 314 1985). 
317 The Bostwick consistency (BC) indices for all (non-) mechanical and/or enzymatic treated mango 318 purée is shown in Fig. 3A-E. For mechanical treatment only (Fig. 3A), non homogenized purée 319 was considered as the control sample and compared with purée homogenised at 20, 60, and 100 $320 \mathrm{MPa}$. The $\mathrm{BC}$ of non homogenised mango purée was $6.6 \mathrm{~cm}$. Statistical analysis showed no 321 significant difference between the BC indices of homogenised mango purées including the control 322 sample.

323 When enzymatic treatment only was applied, except for the cellulase treated purée, BC indices 324 (Fig. 3B) indicated a clear significant improvement (reduced consistency) compared to the non enzymatically treated purée. It is obvious that applying cellulase, had no effect on BC compared to the control. However when pectin polymers were demethoxylated and depolymerised by PME and PG, less resistence to flow was observed. Depolymerization of starch by $\alpha$-amylase also decreased the consistency $(9.9 \mathrm{~cm})$ compared to the control purée $(6.6 \mathrm{~cm})$. The combination of all enzymes resulted in a two-fold decrease in BC index of mango purée compared to non enzymaticaly treated purée and a significant decrease was also observed compared to the use of "PG and PME" only. However by using the mixture of all enzymes and degrading starch on the one hand and demethoxylating and depolymerising pectin on the other hand, no additional effect on decreasing consistency was observed compared to "PG and PME" and " $\alpha$-amylase" only.

334 When the combination of the HPH and enzymatic treatment was used, the pressure level of 20 $335 \mathrm{MPa}$ was selected because of two practical reasons. On the one hand and based on the results 336 from the mechanical treatment only, no significant effect on the $B C$ indices were observed as the 337 pressure level further increased. On the other hand homogenization of a very viscous non diluted 338 purée at higher pressure levels was practically inconvenient. 
339 The $\mathrm{BC}$ indices for the purée which was first homogenised (20 MPa) and then enzymatically 340 treated are reported in Fig. 3C. The BC indices of homogenized and enzymatically treated purée 341 showed a similar trend in consistency reduction as the enzymatic treatment only. However the 342 effect of "all enzymes" after homogenization $(12.8 \pm 0.4 \mathrm{~cm})$ on the consistency decrease was 343 significantaly $(p<0.05)$ larger than the effect of "all enzymes" only $(10.6 \pm 0.2 \mathrm{~cm})$. Additionally, 344 unlike the enzymatic treatment only (Fig. 3B), when enzymes were applied on the homogenised 345 purée (Fig. 3C) a significant difference in BC indices was observed for "all enzymes" compared 346 to "PG and PME" and " $\alpha$-amylase" treated purées.

347 If HPH is applied immediately after the addition of enzymes a significant but a small increase was 348 observed for BC indices of purée treated with " $\alpha$-amylase", "PG and PME", and a combination of 349 all enzymes compared to HPH treated purée (control of this set of treatment) (Fig. 3D). 350 Comparison of the Fig. 3B, 3C, and 3D showed that when mechanical treatment was combined 351 with enzymatic treatment, the order of these two treatments plays a crucial role in determining the 352 mango purée consistency especially in case of "all enzymes". While enzymatic treatment of the $353 \mathrm{HPH}$ treated purée significantly increased the consistency index $(12.8 \pm 0.4 \mathrm{~cm})$ (Fig. $3 \mathrm{C}$ ) 354 compared to enzymatic treatment only $(10.6 \pm 0.2 \mathrm{~cm})$ (Fig. 3B), the consistency index showed a 355 significant decrease when HPH was applied immediately after the addition of enzymes $(7.4 \pm 0.4$ $356 \mathrm{~cm}$ ) (Fig. 3D). This is possibly due to the enzymatic activity during a short inevitable holding time 357 before the start of the homogenisation. After HPH, however, the rearrangement of the polymers 358 due to the breakage of the particles induced by HPH treatment might decrease the substrate 359 accessibility for the enzymes. This might be the reason for the small furthur improvement of BC 360 indices observed, after the incubation time compared to control (Fig. 3D).

361 When HPH treatment was applied on enzymatically treated and incubated purée, no significant 362 increase of BC indices was observed (Fig. 3E). From Fig. 3B, it was concluded that the enzyamitc 363 treatement only, reduces the consistancy, so it is clear that the HPH treatment of enzymatically 
364 treated purées resulted in an opposite effect. It seems that after the degradation of the polymers

365 by enzymes, some polymer and particle rearrangements were induced by homogenization, 366 resutling in an unexpected increase of consistency (Jamsazzadeh Kermani et al., 2015). It can be 367 hypotheised that such rearrangements might lead to the formation of a structured network and 368 subsequently increase the purée resistance to flow. However the mechanism of how 369 homogenisation of enzyamtically treated purée induced the consistency increase is not clear and 370 requires further research.

3.3. Effect of mechanical and enzymatic treatment on the particle size of mango purée

373 The volumetric PSD for all (non-) mechanical and/or enzymatic treated mango purée is presented 374 in Fig. 4A-E.

375 As shown in Fig. 4A, a bimodal particle size distribution is observed for the non homogenised 376 purée, with maximum peaks around 100-200 $\mu \mathrm{m}$ and 600-700 $\mu \mathrm{m}$ particle diameter. As it was expected, HPH clearly decreased mango purée particle sizes. By increasing the homogenization pressure up to $100 \mathrm{MPa}$, particle size reduced to almost 10 times smaller compared to the particles of non homogenised purée. These small particles resulted from breaking of the large particles, led to a purée having more homogenous particle size distribution. As no significant differences were observed between BC indices of HPH treated purées compared to the non-homogenised one, it is striking that the particle size was not such an important factor in determining the consistency of mango purée. However, one should keep in mind the importance of both phases (particle and serum) to the final consistency observed. It was previously reported that a decrease in particle size reduces the viscosity for systems such as apple purée (Espinosa et al., 2011), hence it is possible that the decrease in particle size, reduced the consistency, but on the other hand an increase in polymers concentration in serum due to the release of the soluble cell content 
simultaneously increased the consistency and masked such effect (Jamsazzadeh Kermani et al., 389 2015).

Comparison of the PSDs for enzymatically treated purées (Fig. 4B) showed that for all treated purées a bimodal PSD profile with similar average sizes as for non enzymatic treated purée was present. However, the ratios between the peaks in the bimodal distribution changed. Such purées also showed an increase in BC indices (Fig. 3B). While the purée treated with cellulase (with no significantly different $\mathrm{BC}$ compared to control) had a similar ratio for both peaks compared to the non enzymatic treated purée, for purées treated with $\alpha$-amylase and all enzymes a visible change in ratio of the peaks around $100-200 \mu \mathrm{m}$ and $600-700 \mu \mathrm{m}$ compared to the non enzymatic treated purée was observed. A decrease in the volume percentage of particles with diameter around 600$700 \mu \mathrm{m}$ resulted in volume based increase in particles with diameter around 100-200 $\mu \mathrm{m}$. Moreover, the combination of all enzymes also led to a significant increase in the volume occupied by small particles with sizes around 1-20 $\mu \mathrm{m}$. As $\alpha$-amylase was the common enzyme present in both these treated purées, it can be suggested that the observed decrease in volume percentage 402 of the particles with diameter around 600-700 $\mu \mathrm{m}$ compared to non-treated, "cellulase", and "PG 403 and PME" treated purée was partially due to the starch degradation by a-amylase. While for "PG 404 and PME" treated purée no specific changes on the PSD profile was observed, there was a 405 significant difference in the BC index compared to the control purée. This observation 406 strengthened our previous conclusion based on PSD profile (Fig. 4A) and BC indices (Fig. 3A) of $407 \mathrm{HPH}$ treated purée, that for mango purée the particle size is not the major factor responsible for 408 consistency differences observed.

409 Fig. 4C represents the volumetric PSD of the purées, which are initially homogenised and 410 subsequently treated with enzymes. It is noteworthy that when homogenised purée was treated 411 with enzymes, changes in the volumetric PSD profile due to the enzymatic treatment were limited 412 to "all enzymes" and "PG and PME" treated purées, in which the PSD profile showed more 
413 homogenity, having a sharper main peak. The presence of PG and PME resulted in a small

414 increase in particles with a diameter around 1-20 $\mu \mathrm{m}$. By and large, use of HPH before using a 415 combination of all enzymes, did not significantly change the PSD profile, however a significant 416 decrease in $\mathrm{BC}$ index was observed for HPH purée treated with combination of all enzymes.

417 By changing the sequence of the treatment being first an enzymatic treatment immediately 418 followed by HPH (Fig. 4D), different PSD profiles were observed for "cellulase", "PG and PME", 419 "all enzyme" purées compared to the control purée. Althought it was previously stated that 420 enzymes alone did not induce a dramatic influence on the PSD profile, particles treated with 421 different enzymes did not respond similarly to the subsequent HPH treatment as is infered from 422 Fig. 4D. The short holding time between the addition of enzymes and HPH treatment seemed to 423 be sufficient for enzymes to sensitise particles to the mechanical treatment especially for purées 424 treated with PG and PME, and the combination of enzymes resulting in the formation of smaller 425 particles due to HPH compared to control purée (Fig. 4D).

426 The volumetric PSD of the purées that were enzymatically treated for $1 \mathrm{~h}$ and consequently 427 homogenised is shown in Fig. 4E. An increase in the volume occupied by small particles $(0.1-10$ $428 \mu \mathrm{m}$ ) was observed after homogenisation of purée incubated with "PG and PME" and "all enzymes" 429 compared to only homogenised purée (control of this set of treatment). Generally, the vast 430 numbers of small particles occupied the same volume for which far less numbers of large particles 431 are required. It is striking that pectin degrading enzymes had a clear impact on the cell wall 432 polymers present in particle phase in such a way (Jamsazzadeh Kermani et al., 2015) that after 433 homogenisation, significant numbers of particles with more than 10 times smaller size were 434 produced compared to only $\mathrm{HPH}$ treated purée. It seems that the appearence of these small 435 particles resulted in the suggested rearrangement of polymers leading to the high consistency of 436 purée (Fig. 3E) obtained with such an order of treatments. 
438 The average diameter of a mango tissue cell is between 80 to $150 \mu$ m (Joyce, Shorter, \& Hockings, 439 2001). Consequently, based on the PSD results, the non homogenised non enzymatic treated 440 purée consisted mainly of clusters and partially particles with the size of individaul cells. Increasing 441 the intensity of the high pressure homogenisation treatment increased the volume percentage of 442 the smaller particles. As the measurement of particle sizes by light scattering technique is based 443 on spherical particles, and the tissue based particles of fruit suspensions are anisotropic in shape 444 (Lopez-Sanchez et al., 2011), from the PSD results only, no conclusion can be made regarding 445 particle morphology. Hence it is not clear whether those small particles are individaul cells or 446 anisotropic remnants of neighboring cells. The knowledge of particle morphology helps us to better 447 describe whether the decrease in particle sizes was mainly the result of cell breakage or cell 448 separation. Depending on the mechanism behind the particle size reduction (cell breakage or cell 449 seperation), the composition of the serum largely differs. Cell breakage is believed not only to 450 increase particle numbers (concentration), but also to induce cell content release and to increase 451 the serum polymer (particularly starch) concentration, while cell separation increases particle 452 numbers as well as the possible pectin polymer concentration of the serum by partial solubilisation 453 of pectin from middle lamella (Jamsazzadeh Kermani et al., 2015).

454 Microscopic images were used not only to confirm the size, but more importantly the morphology 455 of the particles. On the micrographs of Fig. 5, purée particles obtained after HPH at 20, 60, 100 456 MPa were stained with toluidine blue (Fig. 5A) and iodine solution (Fig. 5B) to generally stain the 457 cell wall material and starch polymers, respectively. Increasing the intensity of the HPH treatment 458 led to drastic changes in the morphology of the mango purée particles. It is clear from Fig. 5A that 459 the particles had "rough edges" (Lopez-Sanchez, Chapara, Schumm, \& Farr, 2012) not only for 460 the control but also for all homogenised purées ranging from compact clusters (20 MPa, $60 \mathrm{MPa})$ 461 to broken cells (60 MPa, $100 \mathrm{MPa}$ ). Microscopic images (Fig. 5A) showed that the decrease in 
particle size by intensive mechanical treatment was mainly due to the cell breakage. The $\mathrm{pH}$ of 463 the mango purée during the first blanching step $\left(95^{\circ} \mathrm{C}\right.$ for $8 \mathrm{~min}$ ) was $4.2 \pm 0.1$, and $\beta$-elimination reactoin (a chemical depolymerisation reaction of pectin at $\mathrm{T}>80^{\circ} \mathrm{C}$ and low acid and alkaline $\mathrm{pH}$ ) (Sila et al., 2009) might partially degrade pectin under such conditions. However particles measured as the size of mango cells (Fig. 4A), were hardly individual cells in any of the (non) homogenised samples (Fig. 5A). One can conclude that the middle lamella in mango fruit parenchymatous tissue was not heat labile, and the heat load in the first blanching step and/or the $\mathrm{pH}$ did not result in pectin degradation in this layer to make the mango tissue and purée particles consisting of cell clusters, susceptible to cell separation by blending or $\mathrm{HPH}$, respectively. Hence during the two mechanical steps of purée preparation, i.e. blending and $\mathrm{HPH}$ (intensive disruption),

472 cells were broken across the cells, resulting in formation of particles with rather more anisotropic 473 shapes with rough surfaces. On the one hand the cell breakage released the gelatanised starch, 474 which was previously located inside the cells, to the serum phase, increasing the concentration of 475 this phase. On the other hand it induces the formation of many sharp edges on particle surfaces. 476 Although the size of the particles became smaller due to HPH and hence less resistence to flow 477 was expected, it can be suggestted that the formed sharp edges increased the friction and/or 478 induced better association of the particles increasing the resistence to flow. Or it could be that by 479 breaking cells starch granules were released into the serum phase and increase the consistency. 480 These two counteracting effects, resulted in in lack of consistency change due to $\mathrm{HPH}$.

481 As seen in Fig. 5B, HPH also decreased the size of the gelatinised starch granules, that have 482 been released from the cells to the serum phase.

483 Modification of the cell wall material by enzymatic treatment was also visualised with toluidine blue 484 and is presented in Fig. 6A. Clear differences in particle morphology were observed using different 485 enzymatic treatments. For the control purée, not only the sharp edges were observed on the 486 surface of the clusters, but also stained closed circles spreading over each of the cells (inside of 
487 the cluster). As stated before, sharp edges were an indication for cell breakage, however the 488 stained closed circles on the cell surfaces indicated that cell separation also occurred on milieu of 489 such circles supposed to connect different cells. It seems that the cell separation was selective for 490 junctions zones, and the cell breakage was selective for middle lamella. When purée was treated 491 with cellulase, the morphology of the particles did not change. However the cell wall material was 492 less densely stained due to the digestion of cellulose. For " $\alpha$-amylase" treated purée, the cell wall 493 seemed to be thicker compared to the control. Perhaps degradation of the free gelatinised starch 494 in the serum phase by a-amylase, freed and mobilised the water in the system which was 495 previousely captured by starch during gelatinization. This phenomenon helped part of the pectin 496 of the particle phase to absorb that freed water inducing thicker cell wall observed. For "PG and 497 PME" treated purée and when the combination of all enzymes used, significant changes in the 498 morphology to complete disruption of the particles, respectively were observed. This shows that 499 the enzymatic degradation of pectic polymers is not only limited to soluble polymers in the serum 500 phase but also pectic polymers of the particles that are playing a cruicial role in cell wall integrity.

501 The microscopic images of non-/enzymatically treated mango purée stained with iodine solution 502 are also presented in Fig. 6B. The size of the starch granules in mango was reported to be $10 \mu \mathrm{m}$ 503 (Bello-Pérez, paricio-Saguilán, Méndez-Montealvo, Solorza-Feria, \& Flores-Huicochea, 2005), so 504 the observed giant stained areas (Fig. 6B) are the granules that continue to expand by hydration 505 of amorphous region to a greatly swollen reticulated mesh like network, but still held together by 506 persistent micelles via hydrogen bonds in the non-disrupted possible crystelline regions (Swinkels, 507 1985). The swollen starch (dark purple), still located inside the cells, can be clearly observed for 508 the control purée and purées treated with cellulase and the combination of PG and PME. It is 509 interesting that for "PG and PME" treated purée, in which the cell walls became disintegrated (Fig. $5106 \mathrm{~A})$, less intense staining was observed. This might be ascribed to the increased mobility of the 511 water towards the starch granules through the cell wall after the enzymatic treatment, leading to 
512 increase in swelling of the starch in the final blanching step and hence less intense staining with

513 iodine solution. The presence of swollen granules in non a-amylase treated purée indicated that

514 gelatinised starch are still integrated even after the high temperature blanching and the blending

515 shear used. Although the total amount of starch in ripe mango is reported to be limited, it should

516 be considered that even such little amounts, if not hydrolysed, could make a composite gel

517 network of swollen amylopectin-enriched granules in an interpenetrating amylose gel matrix

518 (retrogradation) after the subsequent cooling and during storage (bd Karim, Norziah, \& Seow,

519 2000; Miles, Morris, Orford, \& Ring, 1985). This process seems to contribute to consistency

520 increase in the final product (bd Karim et al., 2000), indicating the importance of selecting proper

521 enzymes based on the biological source. For purées treated with a-amylase and all enzymes, no

522 stained starch could be found. One must take this into consideration that staining of starch with

523 iodine solution is based on the formation of an amylose-iodine complex. When amylose is present

524 in the form of a helix, a core of iodine molecules can be formed inside the helical structure. The

525 formed complex is responsible for the blueish color (Gilbert \& Marriott, 1948). However, the blueish

526 color is only obtained when the amylose chain consists of not less than 45 glucose units (Wilding,

527 1965). The absence of iodine solution staining for the purées treated with a-amylase and all

528 enzymes does not necessarily mean that no starch polymers were present, but it shows that starch

529 might still be present probably not in the form of helices (< of 6 glucose units) and/or that the chain

530 length of the remaining amylose helices is less than 45 glucose units to form the color. Lack of

531 starch staining even when "PG and PME" were not used, showed that all starch in mango purée

532 was accessible by $\alpha$-amylase.

533 3.5. Relation between Bostwick consistency and parameters influenced by $534 \quad$ enzymatic and HPH treatment

535 To identify the main parameters influencing mango purée consistency, a correlation plot between 536 different parameters of the serum and particle phase in this paper and previous work 
537 (Jamsazzadeh Kermani et al., 2015) as influenced by the enzymatic treatments and the 538 combination of $\mathrm{HPH}$ and enzymatic treatment is shown in Fig. 7. In general, the amount of serum 539 is the only parameter that had a strong and positive correlation with BC index, meaning that 540 release of water, most likely with some degraded polymers into serum, increased the BC index 541 (decrease consistency). On the other hand no correlation was observed between BC index and 542 the amount of estimated pectin of serum indicating that soluble pectin was not the main polymer 543 defining the consistency of the mango purée. Rather strong negative correlation was observed 544 between BC index and DM of the serum. As together with PME, PG was also always used and as 545 low methoxylated pectin is a preferred substrate for PG, it can be concluded that low DM was 546 corresponding with relatively lower $M_{w}$ of pectin polymers due to the break down of pectin $\mathrm{HG}$ 547 backbone. Such polymers however were supposed to be extremely branched as no side chain 548 degrading enzymes was used for such treatments. However this hypothesis is not in full 549 agreement with rather strong negative correlation between the DM and $M_{w}$ of polymers of the 550 serum. The reason for this negative correlation is that $M_{w}$ was calculated for all serum polymers 551 assuming the same $\mathrm{dn} / \mathrm{dc}$ such as starch and pectin. The lack of correlation between the BC index 552 and amount of estimated serum pectin is not in agreement with previous data observed for the 553 tomato sera by Moelants et al. (2012). The aouthors showed that the amount of pectin affected 554 the viscosity of the tomato sera. This might be explained by different polymeric composition of 555 tomato and mango suspentions for which starch showed to be one of the main contributing factors 556 for purée consistency.

557 The negative correlation between the BC index and the DM of pectic polymers was stronger than 558 the correlation of the consistency index and the $M_{w}$ of the serum, which was another evidence that 559 pectin was not the only polymer contributing to the consistency. One must take into consideration 560 that although the polymers of particle phase and particularly pectin polymers were largely 561 influenced by the enzymatic and the combination of HPH and enzymatic treatment, such water 
562 solublised polymers were still part of non soluble particle phase, and did not or even negatively 563 correlate with the consistency of the mango purée.

564 As is clear from the correlation plot, particle sizes are strongly and negatively correlated with both 565 the amount of serum and the BC index. However from our results the mechanism behind this 566 correlataion is not completely clear.

\section{Conclusion}

568 In this research, it was observed that the high consistency of mango purée can not be solely 569 related to pectin polymers and their modifications. Other polymers such as starch and cellulose 570 are also contributing to the high consistency observed whether directly (starch) or indirectly 571 (cellulose). It was also observed that the enzymatic treatment significantly changed particle 572 morphologies. Our results suggest that particle morphology is an important factor in consistency 573 changes in mango purée. The sequence by which the enzymatic and mechanical treatments is 574 applied are crucial to the final consistency observed. When the mechanical treatment is followed 575 by the enzymatic treatment, the largest decrease in consistency was observed probably due to 576 the higher accessibility of the enzymes to the polymeric material. Based on the comparison 577 between the BC indices and microscopic images of homogenised and non-homogenised mango 578 purée, it was concluded that the particles size and release of cell content due to the cell breakage 579 was not a determining factor for mango purée consistency. When the purée was first homogenised 580 and then a combination of enzymes (pectin methyesterase, endo polygalacturonase, $\alpha$-amylase 581 and endo-cellulase) was used the BC index changed by a factor of two. In general, the amount of 582 serum is the main parameter showing a strong and positive correlation with $\mathrm{BC}$ index, meaning 583 that release of water and most likely with some degraded polymers into the serum by the 584 enzymatic treatments increased the BC index (decreased the consistency).

585 While our conclusions may be relvent to many other fruit and vegtable purées, one must take into 586 consideration that direct extrapolation of these results is not advisable without appropriate testing 
due to the large variation of pectin structure and other components within spieces. The results of

588 this study lift the tip of the veil of how the selection of enzymatic treatment, and the sequence of

589 mechanical and enzymatic treatment influence the consistency of purées. No doubt that future

590 reseaerch would benefit from focusing on the relation between the modified structure of starch

591 and cell wall polysaccharides and their observed functionality due the enzymatic and HPH

592 treament. A subject which received little attention in literature related to mango purée processing.

593 Additionally, it would be worthwhile that future research is directed towards the analysis of the

594 sensorial properties of the enzymaically treated samples, as for example the enzymatic conversion

595 of the strach in " $\alpha$-amylase" treated samples might result in a sweeter product without using any

596 added sugar.

\section{Acknowledgements}

598 The authors would like to acknowledge the financial support of the KU Leuven Research Council 599 (METH/14/03) through the long term structural funding - Methusalem funding by the Flemisch

600 Government. A. Shpigelman (A.S.) is a postdoctoral researcher partially supported by EMAIL II 601 project.

602

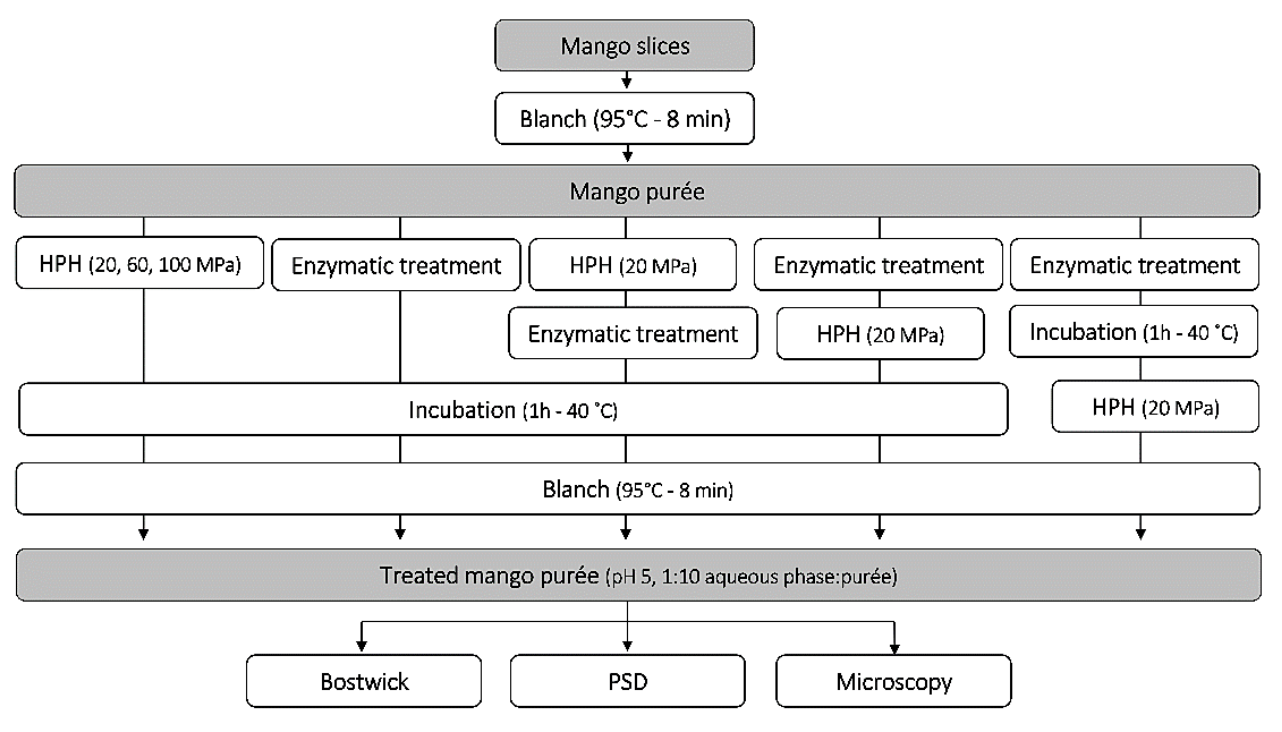


604

605

606

Fig. 1 Schematic overview of the experimental set-up. HPH, high pressure homogenization; PSD, particle size distribution. Enzymatic treatments of purée were treatments with "PME+PG", "a-amylase", "cellulase" alone and "combination of PME, PG, $\alpha$-amylase, and cellulase".

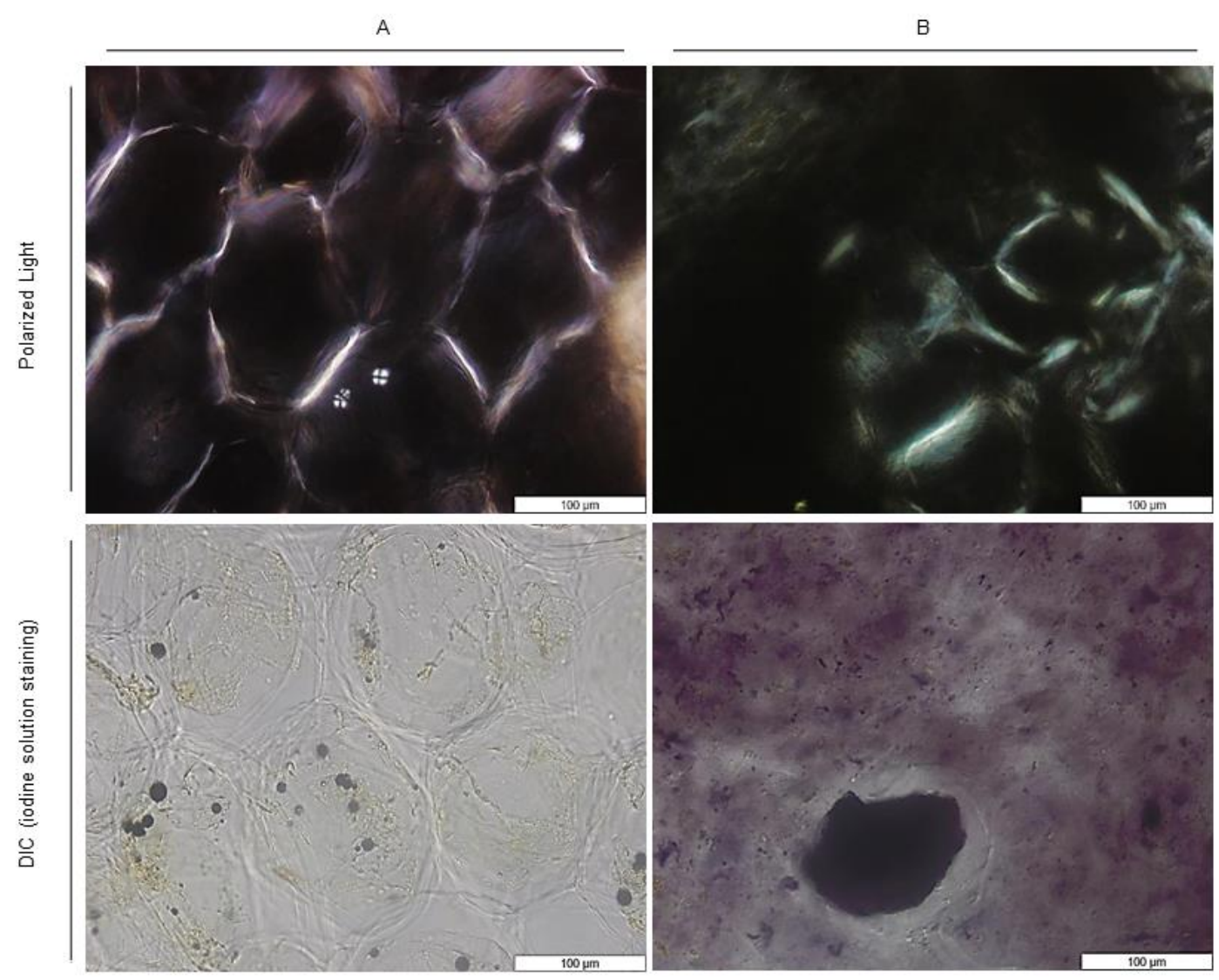

Fig. 2 Microscopic images of (A) mango flesh tissue, and (B) blanched mango purée under polarized light (upper row), and with iodine solution staining under differential interference contrast mode (DIC) (lower row). 

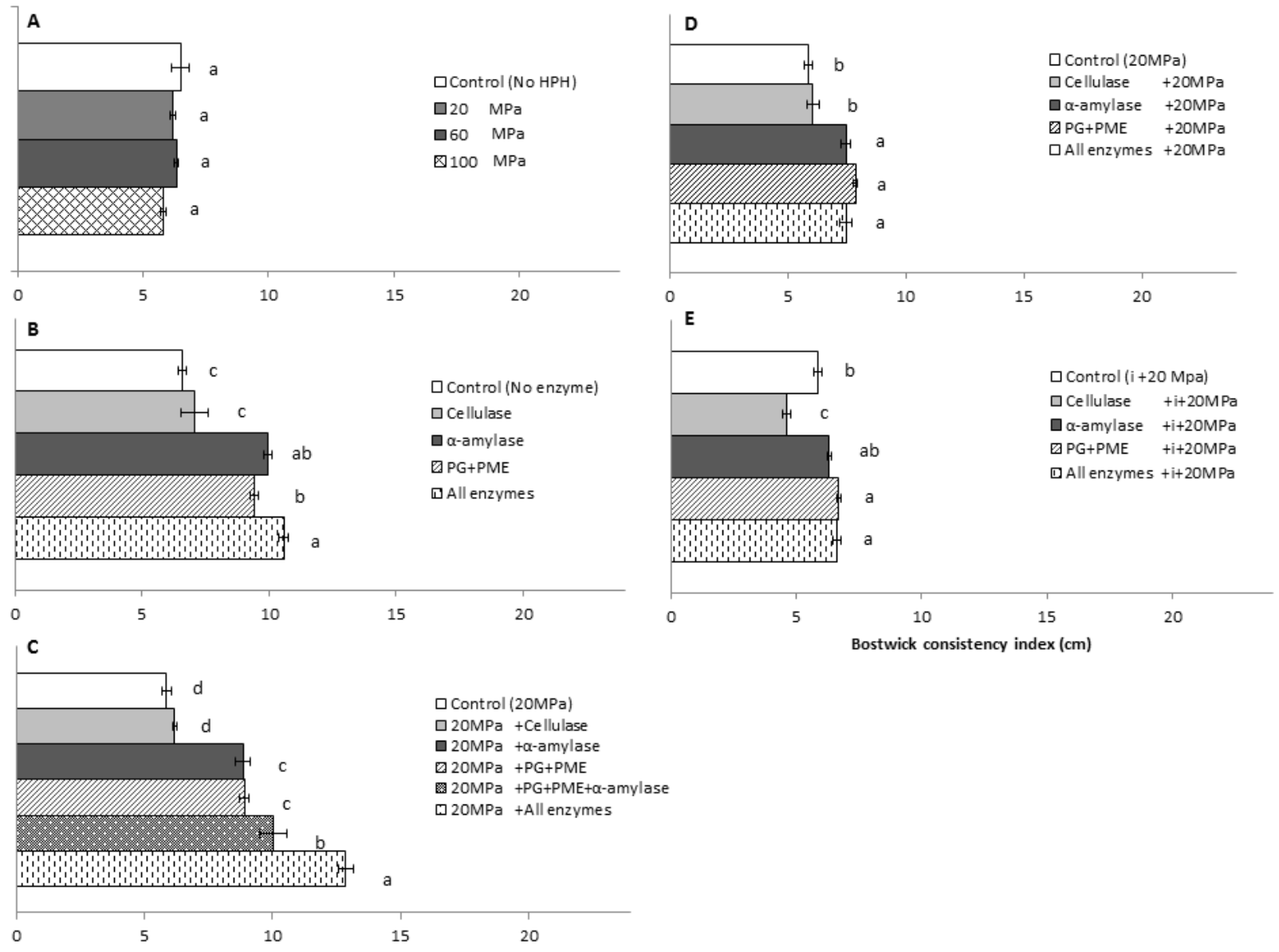

Bostwick consistency index $(\mathrm{cm})$

Bostwick consistency index (cm)

619 Fig. 3 Bostwick consistency index ( \pm standard error, $n=4$ ) of differently mechanical and enzymatic treated 620 purée. (A) mechanical treatment (HPH: high pressure homogenisation), (B) Enzymatic treatment, (C) HPH 621 followed by enzymatic treatment, (D) Enzymatic treatment immediately followed by HPH, (E) incubation of 622 purée with enzymes followed by HPH. "i" stands for incubation. 

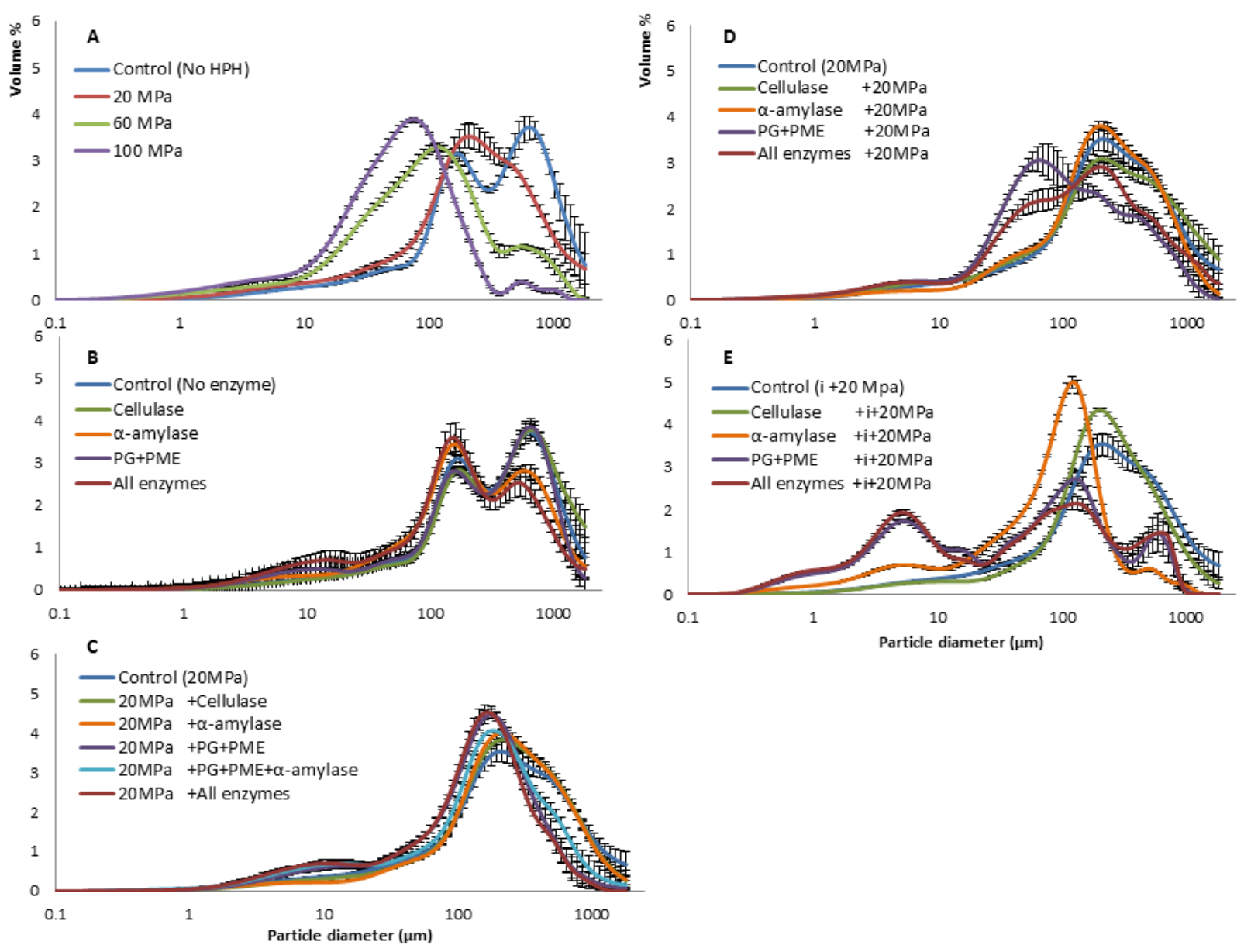

article diameter $(\mu \mathrm{m})$

Fig. 4 Volumetric particle size distribution ( \pm standard error, $n=4$ ) of differently mechanical and enzymatic treated purées. (A) mechanical treatment ( $\mathrm{HPH}$ : high pressure homogenisation), (B) Enzymatic treatment, (C) HPH followed by enzymatic treatment, (D) Enzymatic treatment immediately followed by HPH, (E) incubation of purée with enzymes followed by HPH. For interpretation of the references to colors in this figure legend, the reader is referred to the web version of this article. 
A
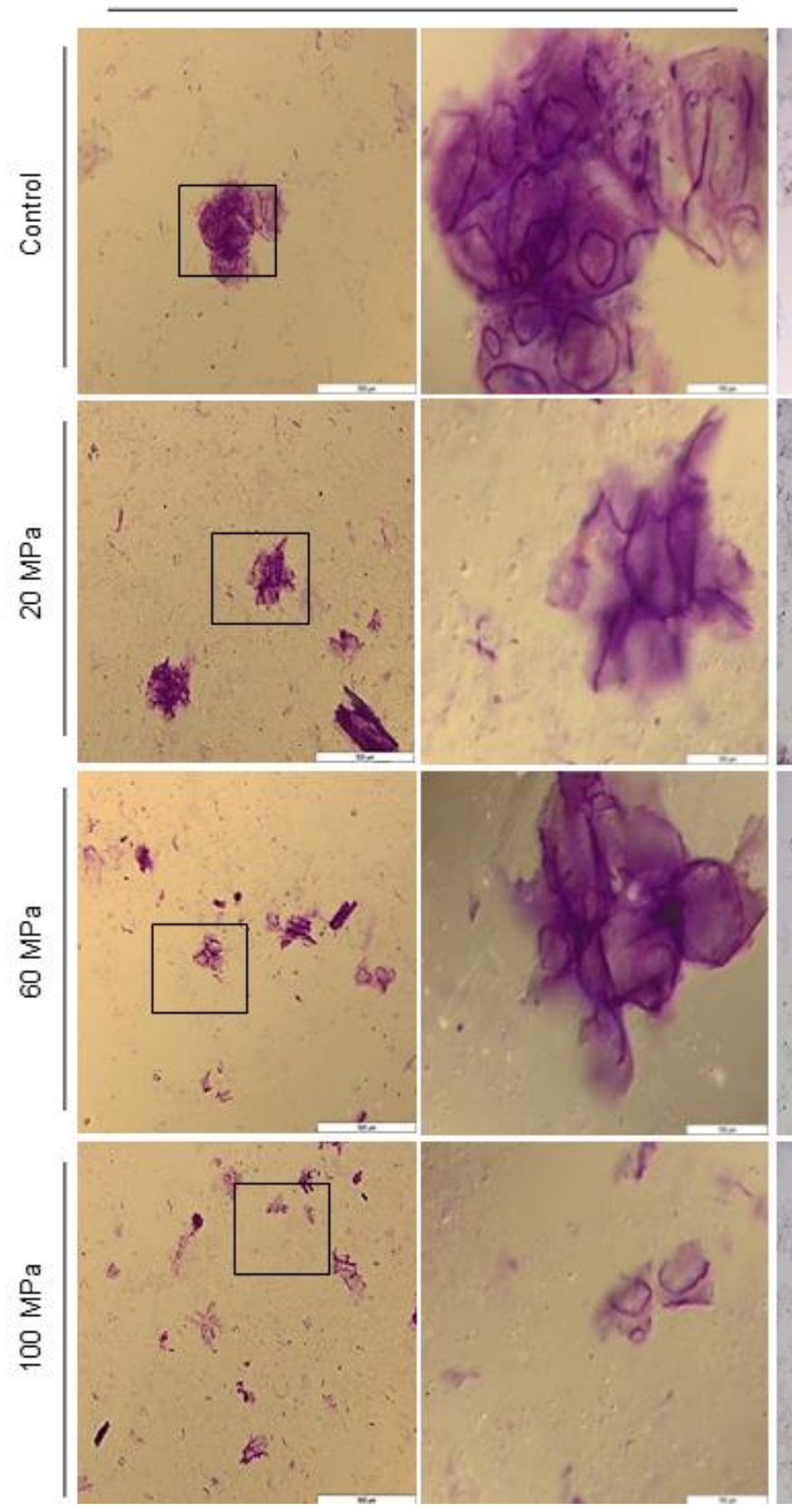
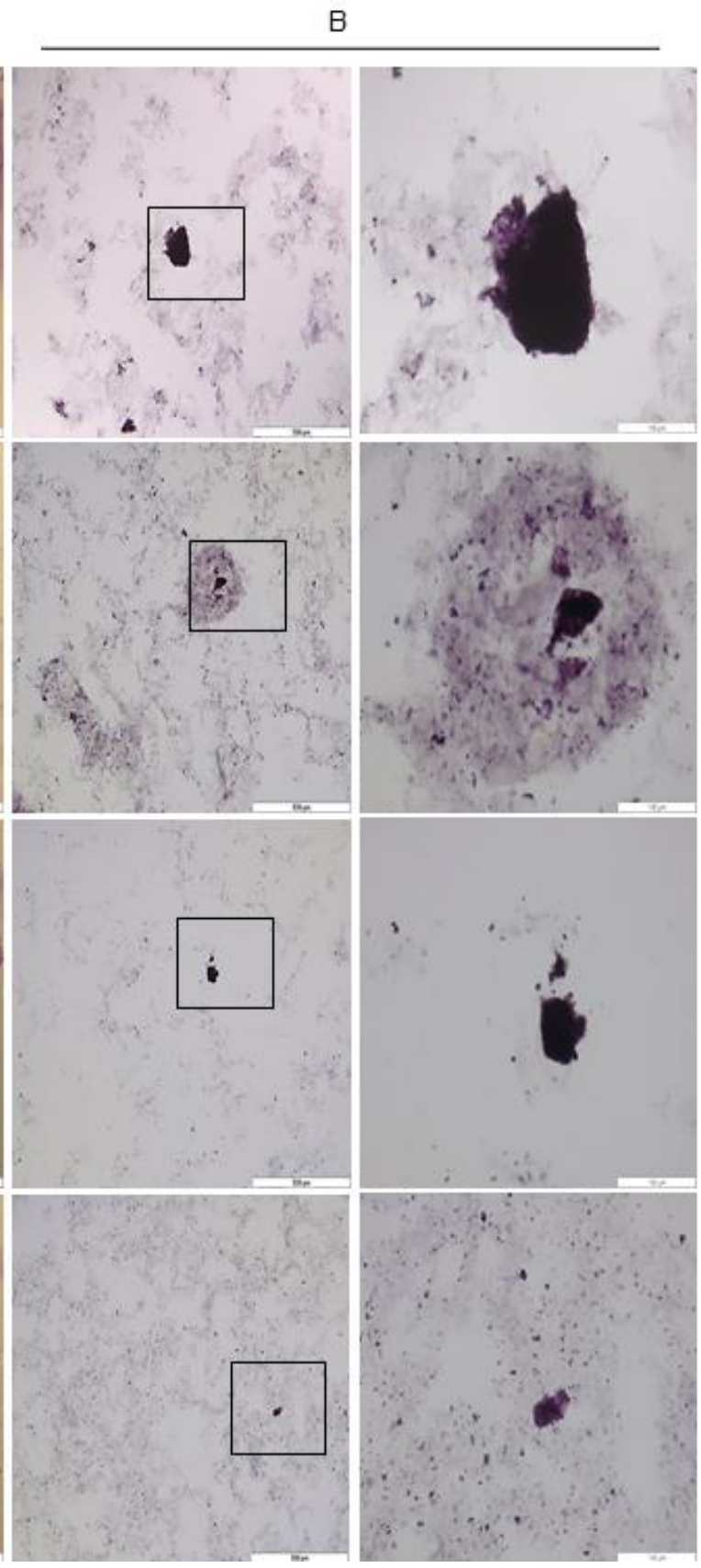

Fig. 5 Microscopic images of high pressure homogenised purée particles stained by (A) toluidine blue and (B) iodine solution. The scale bars for the first and the third column from the left are $500 \mu \mathrm{m}$ and the second 634 and the forth from the left are $100 \mu \mathrm{m}$. 

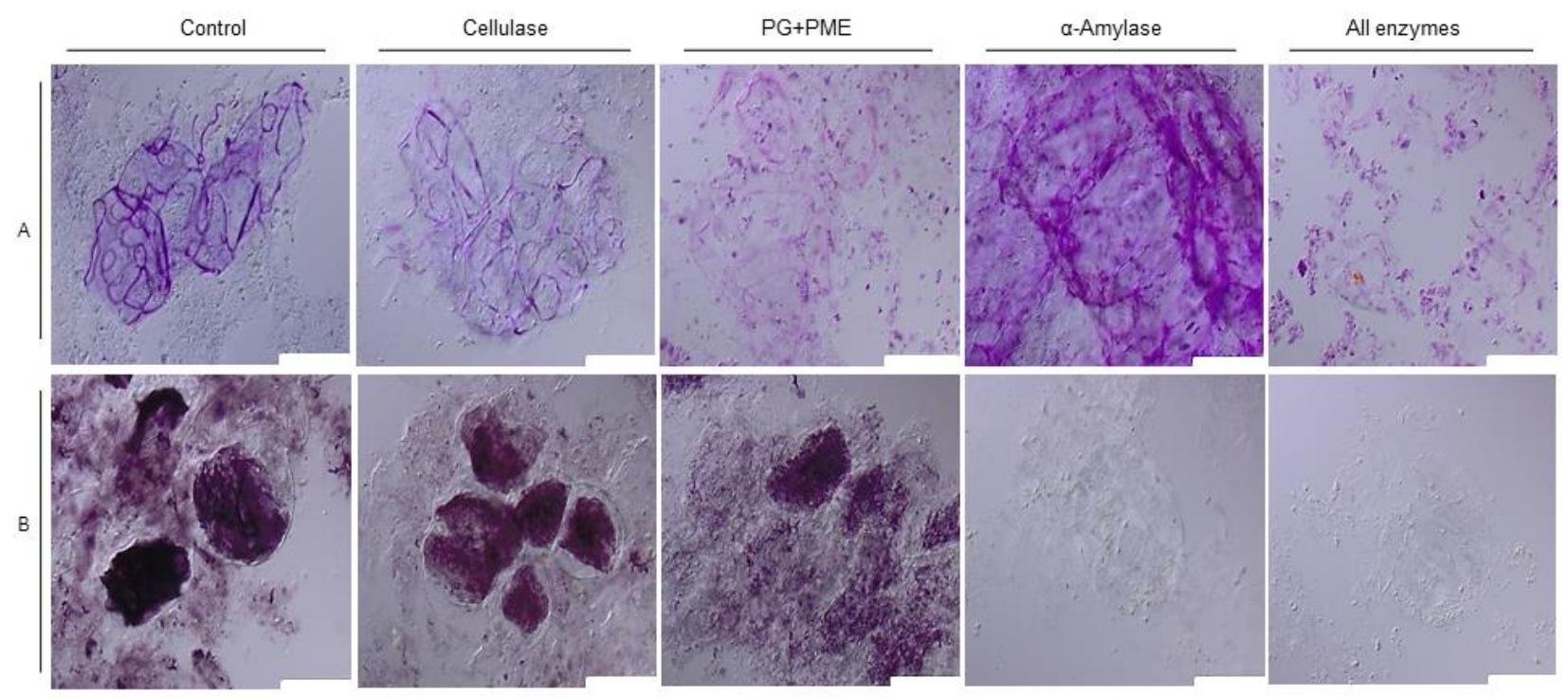

635

636 Fig. 6 Microscopic images of enzymatic treated purée particles stained by (A) toluidine blue and (B) iodine 637 solution. Scale bars $=100 \mu \mathrm{m}$. 
640

641

$B C$ index
g serum $/ 100 \mathrm{~g}$ purée
g UA serum $/ 100$ g serum
DM serum
$M_{w}$ serum

g dialyzed WSF pellet/100g purée

g UA WSF pellet/100 g purée

DM WSF pellet (\%)

$M_{w}$ WSF pellet

Total g UA AIR pellet/100 g purée

Particle size

\begin{tabular}{|c|c|c|c|}
\hline 1.00 & & & \\
\hline 0.84 & 1.00 & & \\
\hline-0.06 & -0.08 & 1.00 & \\
\hline-0.58 & -0.63 & 0.06 & 1.00 \\
\hline-0.25 & -0.14 & 0.25 & -0.34 \\
\hline-0.79 & -0.91 & -0.15 & 0.46 \\
\hline-0.66 & -0.83 & -0.33 & 0.72 \\
\hline-0.61 & -0.57 & 0.12 & 0.99 \\
\hline-0.05 & -0.05 & 0.34 & -0.29 \\
\hline-0.70 & -0.88 & 0.17 & 0.26 \\
\hline-0.58 & -0.68 & 0.61 & 0.42 \\
\hline $\begin{array}{l}\stackrel{\times}{0} \\
\stackrel{0}{0} \\
0 \\
0\end{array}$ & 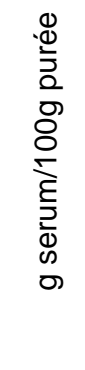 & 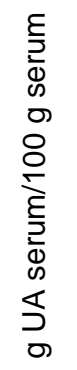 & 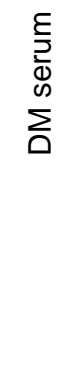 \\
\hline
\end{tabular}

642

643

644

645

646

647

648

649

650

651

652 
653

654

655

656

657

658

659

660

661

662

663

664

665

666

667

668

669

670

671

672

673

674

675

676

677
Table 1. Enzyme activity and incubation $\mathrm{pH}$ for the exogenous enzymes applied.

\begin{tabular}{ccc} 
Enzyme & Activity & Incubation pH \\
\hline Cellulase & $1200 \mathrm{U} / \mathrm{ml}$ & 4.5 \\
\hline $\mathrm{PG}$ & $5000 \mathrm{U} / \mathrm{ml}$ & 5.5 \\
$\mathrm{PME}$ & $35 \mathrm{U} / \mathrm{ml}$ & 6 \\
\hline a-amylase & $2135 \mathrm{U} / \mathrm{g}$ & 6.0 \\
\hline
\end{tabular}

54

(

Ahmed, J., Ramaswamy, H. S., \& Hiremath, N. (2005). The effect of high pressure treatment on rheological characteristics and colour of mango pulp. International Journal of Food Science \& Technology, 40, 885-895.

bd Karim, A., Norziah, M. H., \& Seow, C. C. (2000). Methods for the study of starch retrogradation. Food Chemistry, 71, 9-36.

Bello-Pérez, L. A., paricio-Saguilán, A., Méndez-Montealvo, G., Solorza-Feria, J., \& Flores-Huicochea, E. (2005). Isolation and Partial Characterization of Mango (Magnifera indica L.)

Starch:Morphological, Physicochemical and Functional Studies. Plant Foods Hum Nutr, 60, 7-12.

Bhat, M. K. (2000). Cellulases and related enzymes in biotechnology. Biotechnology Advances, 18, 355383.

Bhattacharya, S. \& Rastogi, N. K. (1998). Rheological properties of enzyme-treated mango pulp. Journal of Food Engineering, 36, 249-262.

Cao, Y. \& Tan, H. (2002). Effects of cellulase on the modification of cellulose. Carbohydrate Research, 337, 1291-1296. 
678 Christiaens, S., Van Buggenhout, S., Chaula, D., Moelants, K., David, C. C., Hofkens, J. et al. (2012). In

679

680

681

682

683

684

685

686

687

688

689

690

691

692

693

694

695

696

697

698

699

700

701 situ pectin engineering as a tool to tailor the consistency and syneresis of carrot purée. Food Chemistry, 133, 146-155.

Combo, A. M. M., Aguedo, M., Goffin, D. e., Wathelet, B., \& Paquot, M. (2012). Enzymatic production of pectic oligosaccharides from polygalacturonic acid with commercial pectinase preparations. Food and Bioproducts Processing, 90, 588-596.

Espinosa, L., To, N., Symoneaux, R., Renard, C. M. G. C., Biau, N., \& Cuvelier, G. +. (2011). Effect of processing on rheological, structural and sensory properties of apple puree. Procedia Food Science, 1, 513-520.

Fellows, P. J. (2000). Fermentation and enzyme technology. In Food Processing Technology: Principles and Practice (pp. 170-195). Taylor \& Francis.

Gilbert, G. A. \& Marriott, J. V. R. (1948). Starch-iodine complexes. Part I. Transactions of the Faraday Society, 44, 84-93.

Grassin, C. \& Fauquembergue, P. (1996). Application of pectinases in beverages. In J. Visser \& A. G. J. Voragen (Eds.), Pectins and pectinases (pp. 453-462). Amsterdam: Elsevier.

Heldt-Hansen, H. P., Kofod, L. V., Budolfsen, G., Nielsen, P. M., Huttel, S., \& Bladt, T. (1996). Application of tailormade pectinases. In J. Visser \& A. G. J. Voragen (Eds.), Pectin and pectinases (pp. 463474).

Jamsazzadeh Kermani, Z., Shpigelman, A., Bernaerts, T. M. M., Van Loey, A. M., \& Hendrickx, M. E. (2015). The effect of exogenous enzymes and mechanical treatment on mango purée: Effect on the molecular properties of pectic substances. Food Hydrocolloids, 50, 193-202.

Jamsazzadeh Kermani, Z., Shpigelman, A., Pham, H. T. T., Van Loey, A. M., \& Hendrickx, M. E. (2015). Functional properties of citric acid extracted mango peel pectin as related to its chemical structure. Food Hydrocolloids, 44, 424-434. 
702

703

704

705

706

707

708

709

710

711

712

713

714

715

716

717

718

719

720

721

722

723

724

Joyce, D. C., Shorter, A. J., \& Hockings, P. D. (2001). Mango fruit calcium levels and the effect of postharvest calcium infiltration at different maturities. Scientia Horticulturae, 91, 81-99.

Kansci, G., Koubala, B. B., \& Mbome, I. L. (2008). Biochemical and physicochemical properties of four mango varieties and some quality characteristics of their jams. Journal of Food Processing and Preservation, 32, 644-655.

Kashyap, D. R., Vohra, P. K., Chopra, S., \& Tewari, R. (2001). Applications of pectinases in the commercial sector: a review. Bioresource Technology, 77, 215-227.

Lopez-Sanchez, P., Chapara, V., Schumm, S., \& Farr, R. (2012). Shear Elastic Deformation and Particle Packing in Plant Cell Dispersions. Food Biophysics, 7, 1-14.

Lopez-Sanchez, P., Nijsse, J., Blonk, H. C. G., Bialek, L., Schumm, S., \& Langton, M. (2011). Effect of mechanical and thermal treatments on the microstructure and rheological properties of carrot, broccoli and tomato dispersions. Journal of the Science of Food and Agriculture, 91, 207-217.

Manohar, B., Ramakrishna, P., \& Udayasankar, K. (1991). Some physical properties of tamarind (Tamarindus indica L.) juice concentrates. Journal of Food Engineering, 13, 241-258.

Manohar, B., Ramankrishna, P., \& Ramteke, R. S. (1990). Effect of pectin content on flow properties of mango pulp concentrates. Journal of Texture Studies, 21, 179-190.

Miles, M. J., Morris, V. J., Orford, P. D., \& Ring, S. G. (1985). The roles of amylose and amylopectin in the gelation and retrogradation of starch. Carbohydrate Research, 135, 271-281.

Millan-Testa, C. E., Mendez-Montealvo, M. G., Ottenhof, M. A., Farhat, I. A., \& Bello-Pérez, L. A. (2005). Determination of the Molecular and Structural Characteristics of Okenia, Mango, and Banana Starches. Journal of Agricultural and Food Chemistry, 53, 495-501.

Mitcham, E. J. \& McDonald, R. E. (1992). Cell wall modification during ripening of 'Keitt' and 'Tommy Atkins' mango fruit. Journal of the American Society for Horticultural Science, 117, 919-924. 
Moelants, K. R. N., Cardinaels, R., Van Buggenhout, S., Van Loey, A. M., Moldenaers, P., \& Hendrickx, M. E. (2014). A review on the relationships between processing, food structure, and rheological properties of plant-tissue-based food suspensions. Comprehensive Reviews in Food Science and Food Safety, 13, 241-260.

Moelants, K., Cardinaels, R., Jolie, R., Verrijssen, T., Buggenhout, S., Loey, A. et al. (2013). Rheology of concentrated tomato-derived suspensions: effects of particle characteristics. Food Bioprocess Technol, 1-17.

Moelants, K., Jolie, R., Palmers, S., Cardinaels, R., Christiaens, S., Buggenhout, S. et al. (2012). The effects of process-induced pectin changes on the viscosity of carrot and tomato sera. Food Bioprocess Technol, 1-14.

Ollé, D., Lozano, Y. F., \& Brillouet, J. M. (1996). Isolation and characterization of soluble polysaccharides and insoluble cell wall material of the pulp from four mango (Mangifera indica L.) cultivars. Journal of Agricultural and Food Chemistry, 44, 2658-2662.

Perona, P. (2005). Bostwick degree and rheological properties: An up-to-date viewpoint. Applied Rheology, 15, 218-229.

Schmelter, T., Wientjes, R., Vreeker, R., \& Klaffke, W. (2002). Enzymatic modifications of pectins and the impact on their rheological properties. Carbohydrate Polymers, 47, 99-108.

Sila, D. N., Van Buggenhout, S., Duvetter, T., Fraeye, I., De Roeck, A., Van Loey, A. et al. (2009). Pectins in processed fruits and vegetables: Part II-structure-function relationships. Comprehensive Reviews in Food Science and Food Safety, 8, 86-104.

Singh, N. I., Dhuique-Mayer, C., \& Lozano, Y. (2000). Physico-chemical changes during enzymatic liquefaction of mango pulp (cv. Keitt). Journal of Food Processing and Preservation, 24, 73-85.

Sreenath, H. K., Nanjundaswamy, A. M., \& Sreekantiah, K. R. (1987). Effect of various cellulases and pectinases on viscosity reduction of mango pulp. Journal of Food Science, 52, 230-231. 
Sreenath, H. K., Sudarshana Krishna, K. R., \& Santhanam, K. (1995). Enzymatic liquefaction of some varieties of mango pulp. LWT - Food Science and Technology, 28, 196-200.

Swinkels, J. J. M. (1985). Sources of starch, its chemistry and physics. In G. M. A. Van Beynum \& J. A. Roels (Eds.), Starch conversion technology (pp. 15-46). Marcel Dekker.

Tibäck, E. A., Svelander, C. A., Colle, I. J. P., Altskär, A. I., Alminger, M. A. G., Hendrickx, M. E. G. et al. (2009). Mechanical and thermal pretreatments of crushed tomatoes: Effects on consistency and in vitro accessibility of lycopene. Journal of Food Science, 74, E386-E395.

Uhlig, H. \& Linsmaier-Bednar, E. M. (1998). Description of enzymes. In Industrial enzymes and their applications (pp. 37-146). Wiley.

Varanyanond, W., Naohara, J., Wongkrajang, K., \& Manabe, M. (1999). Changes in pectin content and average molecular weight of pectin during maturation of the mango" Kaew". Food Science and Technology Research, 5, 362-364.

Verrijssen, T. A. J., Vanierschot, M., Ongena, S. I. M., Cardinaels, R., Van den Bulck, E., Van Loey, A. M. et al. (2014). Role of mechanical forces in the stomach phase on the in vitro bioaccessibility of Bcarotene. Food Research International, 55, 271-280.

Vincken, J. P., Schols, H. A., Oomen, R. J. F. J., Mccann, M. C., Ulvskov, P., Voragen, A. G. J. et al. (2003). If homogalacturonan were a side chain of rhamnogalacturonan I. Implications for cell wall architecture. Plant Physiology, 132, 1781-1789.

Voragen, A., Coenen, G. J., Verhoef, R. P., \& Schols, H. A. (2009). Pectin, a versatile polysaccharide present in plant cell walls. Struct Chem, 20, 263-275.

Wilding, P. (1965). The electrophoretic nature of human amylase and the effect of protein on the starchiodine reaction. Clinica Chimica Acta, 12, 97-104. 
771 Yashoda, H. M., Prabha, T. N., \& Tharanathan, R. N. (2006). Mango ripening: changes in cell wall

772 constituents in relation to textural softening. Journal of the Science of Food and Agriculture, 86,

$773 \quad 713-721$

774

775 